TEME, г. XLIII, бр. 3, јул - септембар 2019, стр. 695-718

\begin{tabular}{lr}
\hline \hline Оригинални научни рад & https://doi.org/10.22190/TEME190513043K \\
Примљено: 13.5 .2019 & UDK 339.137.2:330
\end{tabular}

Ревидирана верзија: 18. 9. 2019.

Одобрено за штампу: 20. 10. 2019.

\title{
COMPETITIVENESS AND INEQUALITY IN INCOME DISTRIBUTION IN THE EUROPEAN COUNTRIES AT DIFFERENT LEVELS OF DEVELOPMENT
}

\author{
Vladimir Kostic ${ }^{1}$, Vojislav Ilić ${ }^{2}$, \\ Slobodan Cvetanović ${ }^{3 *}$, Vladimir Nedić ${ }^{4}$ \\ ${ }^{1}$ University of Kosovska Mitrovica, Faculty of Economics, Serbia \\ ${ }^{2}$ University of Kosovska Mitrovica, Faculty of Arts \& University of \\ Kragujevac, Faculty of Philology and Arts, Serbia \\ ${ }^{3}$ University of Niš, Faculty of Economics, Serbia \\ ${ }^{4}$ Techical college of applied studies in Kragujevac, Serbia \\ *slobodan.cvetanovic@eknfak.ni.ac.rs
}

\begin{abstract}
The paper studies the interdependence of the phenomena of country's competitiveness and inequality in income distribution in respect to the countries of the European continent, divided in two groups: a) the present (Albania, Montenegro, Bosnia and Herzegovina, Macedonia, Moldova, and Serbia) and former members (Bulgaria, Croatia Hungary, Poland, Slovakia, Slovenia, Romania, and the Czech Republic) of the Central European Free Trade Agreement - CEFTA, and b) EU15 countries. The study relates to the period from 2006 to 2013. The first group of countries represents less competitive countries, while the second includes highly competitive European economies. The achieved level of competitiveness is expressed by the values of the Global Competitiveness Index of the World Economic Forum, decomposed into Basic \& Efficiency factors based competitiveness and Innovation \& Sophistication factors based competitiveness. Inequality in income distribution is expressed by the Gini coefficient. Based on the created model of dependence of the Gini coefficient on the above-mentioned components of competitiveness, using simple and multiple linear regression analysis, it has been concluded that the achieved level of competitiveness of some countries has a statistically significant influence on the value of the Gini coefficient. The results of multiple linear regression analysis show that, in the group of CEFTA countries, the influence coefficient of Basic \& Efficiency factors based competitiveness is around -3.8, while for the EU15 group, it is about 2.4. Furthermore, research has confirmed a statistically significant influence of Innovation \& Sophistication Factors based competitiveness on the decrease in the value of the Gini coefficient in both observed groups of countries; in CEFTA group, influence coefficient is about -8.4, and, in the EU15, the influence is somewhat weaker, and amounts to -5.8 .
\end{abstract}

Key words: competitiveness of the country, Gini coefficient, CEFTA, EU15. 
696

\title{
КОНКУРЕНТНОСТ И НЕЈЕДНАКОСТ У РАСПОДЕЛИ ДОХОТКА ЗЕМАЉА ЕВРОПЕ РАЗЛИЧИТОГ НИВОА РАЗВИЈЕНОСТИ
}

\begin{abstract}
Апстракт
У раду је истраживана међузависност феномена конкурентности и неједнакости у расподели дохотка земаља европског континента различитог нивоа економске развијености у периоду 2006-2013. Анализиране земље су подељене у две групе: а) садашње (Албанија, Црна Гора, БИХ, Македонија, Молдавија и Србија) и некадашње чланице (Бугарска, Хрватска, Мађарска, Пољска, Словачка, Словенија, Румунија и Чешка) Централноевропског Споразума о слободној трговини - ЦЕФТА и б) земље ЕУ15. Прва групу представљају мање конкурентне, а другу високо конкурентне европске земље. Достигнути ниво конкурентности је исказиван величином Глобалног индекса конкурентности $(G C l)$ Светског економског форума, декомпонованог на две скаларне вредности: а) тзв. конкурентност засновану на Основним факторима Ефикасности (Basic \& Efficiency factors competitiveness) и б) конкурентност генерисану факторима пословне иновативности и софистицираности (Innovation and sophistication factors competitiveness). Неједнакост у расподели дохотка је презентована величином Гини коефицијента. У циљу доказивања постављених хипотеза да конкурентније привреде имају мање изражену неједнакост у расподели дохотка конструисан је модел међузависности конкурентности привреде (репрезентованом вредностима ГЦИ) и неједнакости у расподели дохотка (квантифициране вредношћу Гини коефицијента). Резултати вишеструке линеарне регресије показују да је код групе ЦЕФТА земаља коефицијент утицаја Basic \& Efficiency factors competitiveness око -3.8, док је код групе ЕУ15 око 2.4. Такође, истраживање је потврдило статистички значајни утицај Innovation and sophistication factors competitiveness на смањење Гини коефицијента код обе групе посматраних земаља; код ЦЕФТА групе коефицијент утицаја је око -8.4 а код ЕУ15 тај утицај је нешто слабији и износи -5.8
\end{abstract}

Кључне речи: конкурентност земље, Гини коефицијент, ЦЕФТА, ЕУ15.

\section{INTRODUCTORY REMARKS}

The subject of this work is the interdependence of the category of country's competitiveness and the phenomenon of inequality in the distribution of income. The aim is to prove that more competitive economies have less pronounced inequality in income distribution (Waheeduzzaman, 2002).

The hypothesis that inequality in income distribution is lower in countries with higher levels of competitiveness is based on the fact that the key determinants of competitiveness of countries vary depending on the reached level of their economic development (Huggins \& Izushi, 2009; Despotović, et al., 2015).

The level of countries' competitiveness is perceived through the value of the Global Competitiveness Index of the World Economic Forum in the period 2006-2013. Special focus is placed on the country's competitiveness generated by the possession and effective use of production factors (Basic \& 
Efficiency factors based competitiveness), on the one hand, and Innovation \& Sophistication factors based competitiveness, on the other (Page \& Vandermeer, 2013; Despotović, Cvetanović \& Nedić, 2014; Aghion et al., 2015). As an indicator of inequality in income distribution, the Gini coefficient is used, as the most commonly used indicator of economic inequality at the national level (Bogliacino, 2013).

This study examines the interdependence of Basic \& Efficiency factors based competitiveness and Innovation \& Sophistication factors based competitiveness and inequality in income distribution, using the model of simple and multiple linear regression analysis, applied to current and former members of the Central European Free Trade Agreement - CEFTA, on the one hand, and EU15, on the other. The first group represents the economically less developed and less competitive countries, while the second includes more developed and competitive European countries.

The composition of the work, in addition to the introduction and conclusion, consists of three chapters. The first part gives a brief overview of the phenomena of the country's competitiveness and inequality in income distribution. The second part explains the WEF GCI framework and the process of defining and developing the model of interdependence of the observed variables on the basis of the above-mentioned WEF GCI framework. The third part rests on the analysis and discussion of research results.

\section{THE COMPETITIVENESS OF THE COUNTRY AND THE INEQUALITY IN INCOME DISTRIBUTION}

Competitiveness refers to the ability of companies, local communities, nation states, and alliances of states to compete and be better, more creative, and more innovative than other stakeholders at the local, national, regional, or global markets in the creation of value added (Dragičević, 2012: 14). The very concept of competitiveness is widely used in the economic literature. A number of economic theorists believe that competitiveness has the status of "a natural law of modern market economy" (Kitson et al., 2004; Martin et al., 2012). Others feel that the definition of competitiveness relates to productivity, which measures the value of goods and services per unit of factors produced in a particular territory (Krugman, 1996; Ketels, 2003). Yet, others insist on the distinction between a country's competitiveness and its productivity. "Competitiveness refers to the extent to which the goods of one country can compete on the market. It depends primarily on the relative prices of domestic and foreign products. Competitiveness must be different from productivity, which is measured by the amount of output per input volume" (Samjuelson i Nordhaus, 2009: 635). Thus, competitiveness aims to achieve higher productivity, which, in turn, affects the growth of living standards and consequently affects the reduction of economic disparities in society. 
It is an undeniable fact that there is no necessary unity of views of economists on key determinants of competitiveness of the country, a category which is of crucial importance for the growth of economic wealth and its distribution methods. Controversy in discussions on the topic of competitiveness in economic theory stem primarily from the fact that this concept does not take into account the limitations arising from the competitiveness being based on the relative positions and the meaning of the phenomenon depending on the level of aggregation at which it is viewed. That is why the study of certain aspects of competitiveness is inevitably associated with great simplification. At the same time, only a small number of determinants of competitiveness of countries may be taken into account. The found differences in competitiveness between countries are usually explained by the different availability and efficiency of use of production factors at lower levels of development, i.e. the demonstrated innovation and business sophistication at the higher levels of economic development of national economies.

The country's competitiveness is closely linked to a rise in living standard and greater job opportunities. Although it is obvious that the country's competitiveness is essentially linked to the quality of its economic performance, the fact is that this category is primarily seen as relative to other countries, much less to its accumulated wealth (Nijkamp Siedschlag and Smith 2011).

It can be said that today there is a consensus on two issues among economists. First, the improvement in the economic performance of a country should not be at the expense of others. Second, productivity is a central problem of competitiveness. Thus, competition aims to achieve higher productivity, which affects the growth of living standard and reduction of inequalities in income distribution.

The priorities of competitiveness improvement policy are changed by switching from one to the next phase of development. In the initial stage of economic development, countries compete based on the relative abundance of production factors. In that stage, the relative costs are the basis of competitiveness. In the next stage, the efficiency and quality of products are of crucial importance, while, for the most economically developed countries, innovation and business sophistication become the critical factor (Sala-iMartin, et al., 2010).

Although there is still no compatible and uniform methodology for measuring competitiveness, practice has given rise to several methodological tools for quantifying the country's competitiveness. However, only the World Economic Forum's Index explicitly uses the term "competitiveness". As defined by the World Economic Forum, the competitiveness is a set of institutions, policies, and factors that determine the level of productivity of a country (Schwab \& Porter, 2007).

The problem of inequality in recent years has become the focus of attention of economic researchers (Gottschalk \& Smeeding, 2000; Huangbao, 
2014; Kawachi \& Subramanian, 2014; Stiglitz, 2015). Economic inequality is most commonly expressed through income. The explanation for this should be sought in the expansion of income differences (within individual countries and between them), as well as in new knowledge about the relationship between inequality and economic development, i.e. improving competitiveness. The view that inequality is determined mainly by the level of economic development (as presented in Kuznets's hypothesis) is gradually being replaced by the attitude on inequality being the determinant of income growth, i.e. productivity growth. Recent research shows that more equal distribution of income through various channels can be a stimulator of economic growth, and, therefore, the factor in improving the competitiveness of countries (Lundvall \& Rodrigues, 2002; Lundvall \& Lorenz, 2012).

Economists have developed a large number of indicators for measuring and ranking different income distribution. These are primarily divided into graphic and numeric indicators. Among the graphic indicators, it is certain that the greatest "popularity' and the practical application belongs to Lorenz curve. However, given the fact that the number is more accurate and concise than the graph, policy makers and researchers often give preference to numerical measures in considering issues of inequality. Numerical indicators allow the comprehensive ranking of income distribution, allocating the appropriate number to each alternative distribution.

Numerical inequality indicators can be classified into two main groups: (a) descriptive and (b) the so-called ethical measures. The descriptive measures include different statistical indicators which are, by their nature, usually measures of dispersion. Unlike them, ethical measures aim to link the inequality of income distribution with the decreased social welfare, which is a consequence of inequality. On the basis of ethical measures of inequality, one can make a conclusion about how much the level of social welfare would be higher if there was equality in income distribution in a society.

The most commonly used indicator of inequality in income distribution is the Gini coefficient. This measure of inequality in income distribution was proposed by the Italian statistician, Corrado Gini, at the beginning of the last century. The Gini coefficient can be directly derived from the Lorenz curve. The graphical presentation makes this measure easy to understand. This approach to measuring inequality is based on comparison of each pair of incomes and the sum of the absolute values of differences in incomes. Inequality in respect of the whole distribution is represented as the sum of inequalities per pairs of income.

The Gini coefficient is a direct measure of inequality. It synthetically shows the disparities in incomes across the entire distribution. The value of the coefficient theoretically ranges from 0 (total equality) to 1 (total inequality). The Gini coefficient can be expressed in percentages of (decimal notation is easily converted to a percentage - by multiplying by 100 ). 
The Gini coefficient has certain shortcomings, which are not negligible. Firstly, this measure is insensitive, because the small changes in the value of the Gini coefficient can hide big changes in the relative incomes of some segments of the observed population. Insensitivity of the Gini coefficient stems from unrealistically set limits that apply to this measure (total equality, i.e. total inequality). In addition, the value of the Gini coefficient can be the same for the two distributions of income that are significantly different.

\section{THE CONCEPT OF SUSTAINABLE COMPETITIVENESS OF COUNTRIES OF THE WORLD ECONOMIC FORUM}

It is increasingly evident that the research on interdependence of categories of competitiveness and inequalities in distribution of income of countries has to be realized by extending the concept of global competitiveness to the category of sustainable global competitiveness. It is a well-known fact that the term sustainable development came into wide use in the 1980s, thus indicating the correlation between economic development and the imperative of environmental protection and overall social development, with the indicator of (in)equality of income distribution as one of the basic dimensions. In short, while on the one hand there is a need for economic development, production and profit, on the other hand, there is the problem of increasing inequality in income distribution and limited natural capital, which calls into question the needs of future generations (Cvetanovic, \& Novakovic, 2014).

The concept of global sustainable competitiveness was promoted by the World Economic Forum in its Global Competitiveness Reports. The methodology for measuring the Global Sustainable Competitiveness Index is based on the premise of the linear impact of environmentally sustainable and socially sustainable dimension of countries' competitiveness. The result is the Global Sustainable Competitiveness Index as an average of two sustainability-adjusted indices: the Global Sustainable Competitiveness Index adjusted to social requirements and the Global Sustainable Competitiveness Index adjusted to environmental requirements (Schwab, \& Sala-i-Martin, 2015, pp. 53-77; Despotovic, et al., 2014).

For social sustainability, the Forum identifies three conceptual elements of social dimension of the Global Sustainable Competitiveness Index: a) access to basic necessities, b) vulnerability to economic exclusion (to shocks), and v) social cohesion. The first category is related to the access of population to basic living needs. It includes three indicators: the access to sanitation facilities, the access to improved quality drinking water and the access to health care services. The second category is associated with the concept of perceived economic security. It attempts to evaluate the vulnerability of population to economic exclusion (vulnerable employment, 
extent of informal economy, social safety, net protection). The third and last category assesses social cohesion. The assessment includes three indicators: Gini coefficient, social mobility and youth unemployment. Excessive inequality can hide relative poverty that would prevent lower-income families from having access to the same opportunities as high-income families.

Environmental sustainability means the existence of an economic system that contains a high degree of stability and the ability to create new value as a real source for alimony of all forms of consumption. In short, it refers to preserving and restoring the biosphere (water, air, temperature, etc.), i.e. bio-geo-chemical characteristics as a framework for biosphere functioning.

For the environmental dimension of sustainable competitiveness, the World Economic Forum identified three conceptual elements: a) environmental policy, b) the use of renewable resources, and g) degradation of the environment. The first area measured in the pillar of environmental sustainability is environmental policy. It consists of the measure of strictness and enforcement of environmental regulations, number of ratified international environmental treaties, together with the extent to which terrestrial areas are protected, which provides an assessment of a country's commitment to natural capital protection. Another area is related to the use of renewable resources. These indicators include: measures of the baseline water stress in an economy (which models the relation between water supply availability and demand); intensity of water consumption in agriculture (which takes into account the level of efficiency of water use in the agricultural sector); forest depletion (which considers the reported and satellite information necessary for assessment of terrestrial areas, forested or afforested over time) and overexploitation of fish stocks. Reduced regeneration opportunities are one of major environmental issues for which a simple solution cannot be easily identified. The third area considers the degradation of environment, which can cause serious damage to human health, simultaneously destroying the ecosystem (level of particulate matter concentration; $\mathrm{CO} 2$ intensity and quality of the natural environment).

\section{RESEARCH METHODOLOGY}

In order to analyze the impact of national competitiveness on economic inequality, a model shown in Figure 1 has been constructed. 


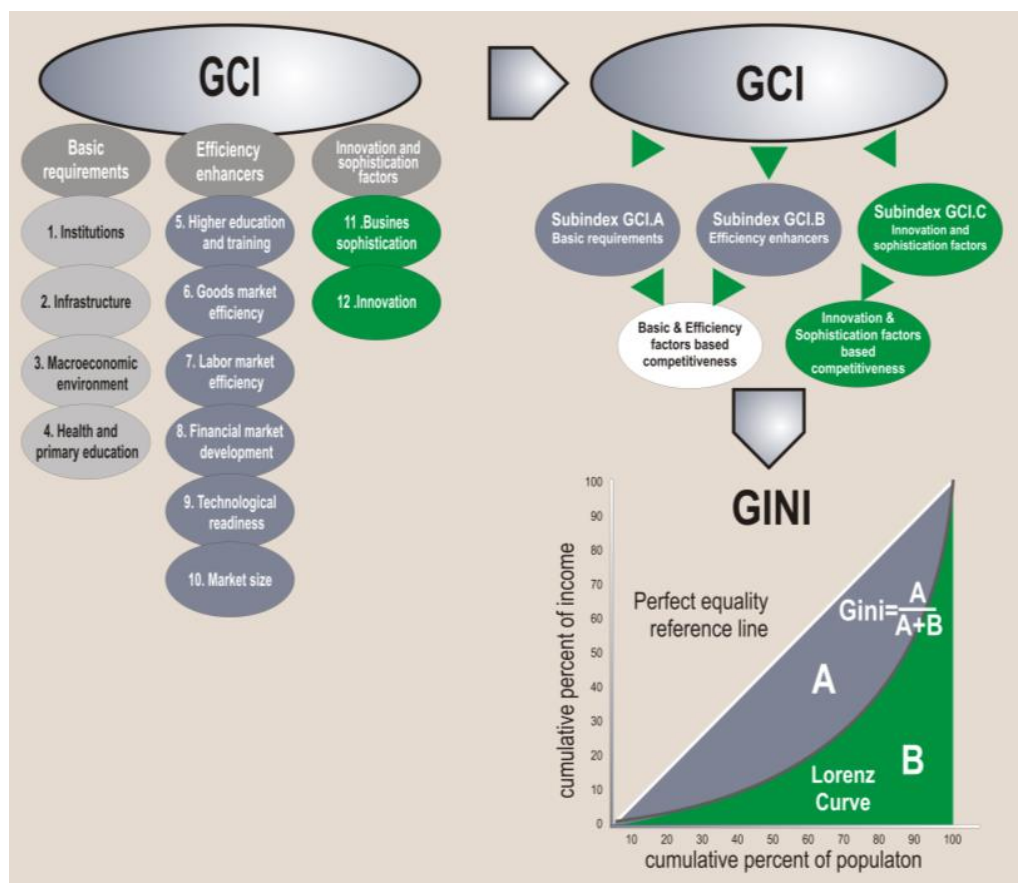

Figure 1 Model applied in the research

The research procedure was carried out in three phases:

1. Analysis of reference literature sources and frameworks to identify the key determinants of national competitiveness;

2. Definition of composite values as representative values: a) national competitiveness based on availability and efficient use of factors (the so-called Basic \& Efficiency factors based competitiveness), and b) national competitiveness generated by factors of innovation and business sophistication (Innovation \& Sophistication factors based competitiveness);

3. Application of statistical tools and analysis of the significance of the proposed model.

The achieved level of competitiveness of the national economy is presented by the value of the Global Competitiveness Index of the World Economic Forum (WEF, 2015; Martin, Schwab \& Porter, 2012). It is a composite index based on 12 pillars of competitiveness, organized into three groups, i.e. sub-indices: a) the first group are the so-called Basic requirements b) the second group includes the so-called Efficiency enhancers; and c) the third group are Innovation and sophistication factors.

The basis for the definition of explanatory variables in the model, a) Basic \& Efficiency factors based competitiveness and b) Innovation \& Sophistication factors based competitiveness, is the above-mentioned GCI 
framework with its 3 sub-indices, while the level of economic inequality is quantified by the Gini coefficient according to the World Bank data (World Development Indicators, World Data Bank, n.d.) and Eurostat (Gini coefficient of equalized disposable income, n.d.).

Competitiveness is represented by the GCI variable, which is a composite value and the function of the three sub-indices: GCI.A (Basic requirements), GCI.B (Efficiency enhancers), GCI.C (Innovation and sophistication factors), as shown in Figure 2 and represented by the following formula

$$
\text { GCI }=\text { GCI.A } * \alpha_{\mathrm{s}}+\text { GCI.B } * \beta_{\mathrm{s}}+\text { GCI.C } * \gamma_{\mathrm{s}}
$$

where $\alpha \mathrm{s}, \beta \mathrm{s}, \gamma \mathrm{s}$ are weights of the sub-index whose values depend on the stage of development of a given economy (Figure 3).

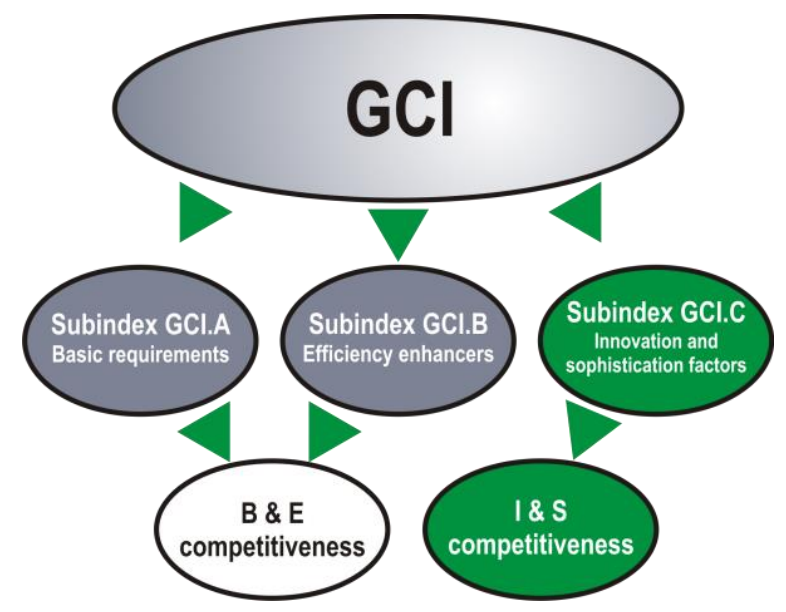

Figure 2 GCI framework

In further research, it is assumed that the sub-index A (Basic requirements) and the sub-index B (Efficiency enhancers) reflect the phenomenon of competitiveness in its base form - Basic \& Efficiency factors based competitiveness ( $B \& E$ competitiveness), and the sub-index $\mathrm{C}$ - Innovation and sophistication factors represents Innovation \& Sophistication factors based competitiveness ( $I \& S$ competitiveness), which decomposes competitiveness into two dimensions.

$B \& E$ competitiveness results from the corrected and normalized average of sub-indices A and B (X1). Correction coefficient is defined based on the weight factors of each GCI sub-index, depending on the achieved level of development of the given economy (Porter, et al., 2004), (Figure 3; Formula 2). 


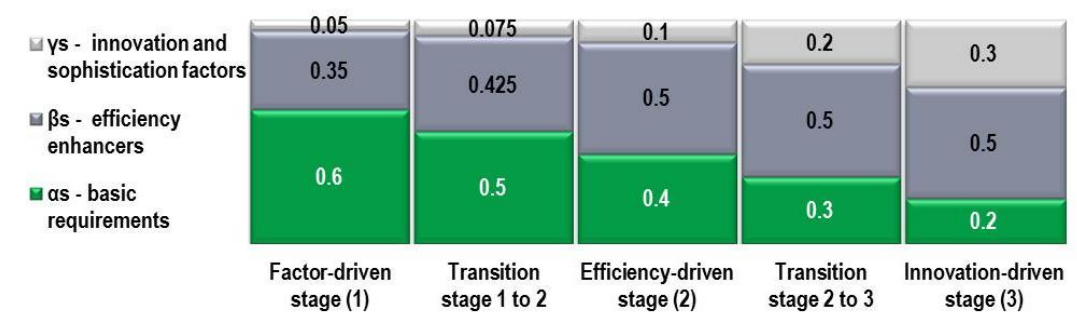

Figure 3 Phases of development and weight coefficients of GCI sub-indices

$$
\mathrm{X} 1=\frac{\left(G C I . A * \alpha_{S I}\right)+\left(G C I . B * \beta_{S I}\right)}{\alpha_{S I}+\beta_{S I}} * 10
$$

where:

$\alpha$ - weight factor of the sub-index GCI.A

$\beta-$ weight factor of the sub-index GCI.B

SI - phase of development of the observed economy where I ranges from 1 to 5

Based on the above-mentioned GCI WEF reference framework, Figure 4 shows the assumed model of influence of the Sub-index GCI A Basic requirements and the Sub-index GCI B Efficiency enhancers (Basic \& Efficiency factors based competitiveness), on one side, and the Subindex GCI C Innovation and sophistication factors (Innovation \& Sophistication factors based competitiveness), on the other side, on the inequality in the distribution, quantified by the Gini coefficient.

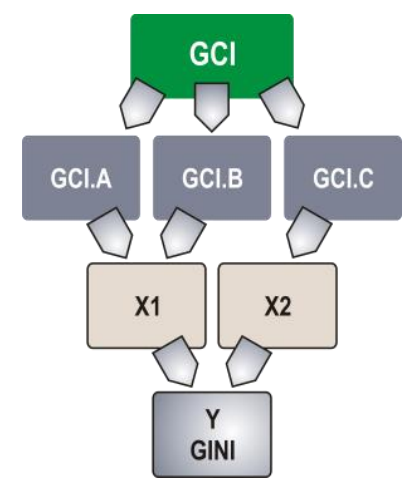

Figure 4 Model of influence

There are the following variables:

GCI.A - Subindex A - Basic requirements

GCI.B - Subindex B - Efficiency enhancers

GCI.C - Subindex C - Innovation and sophistication factors 
$\mathrm{X}_{1}-$ Basic \& Efficiency factors based competitiveness (B\&E competitiveness)

$\mathrm{X}_{2}$ - Innovation \& Sophistication factors based competitiveness (I\&S competitiveness)

$\mathrm{Y}-$ Gini coefficient.

On the basis of the established generic model, shown in Figure 4, dependence of $\mathrm{Y}$ (Gini coefficient) on the independent variables (variables $\mathrm{X}_{1}$ and $\mathrm{X}_{2}$ ) is defined:

where:

$$
\mathrm{Y}=\mathrm{a}_{0}+\mathrm{a}_{1} * \mathrm{X}_{1}+\mathrm{a}_{2} * \mathrm{X}_{2}
$$

$\mathrm{Y}$ (dependent variable) - Gini

$\mathrm{X}_{1}$ (independent variable 1$)-B \& E$ competitiveness

$\mathrm{X}_{2}$ (independent variable 2) $-I \& S$ competitiveness

$a_{i}(i=0-2)-$ are constants acquired from multiple regression process.

The defined model of influence of $B \& E$ competitiveness and $I \&$ $S$ competitiveness on economic inequality has been analyzed over two groups of countries (Milanovic, 2002, pp. 2-3), (Figure 5):

(1). CEFTA - former and current members (CEFTA countries)

(2). EU15 - the first $15 \mathrm{EU}$ member states

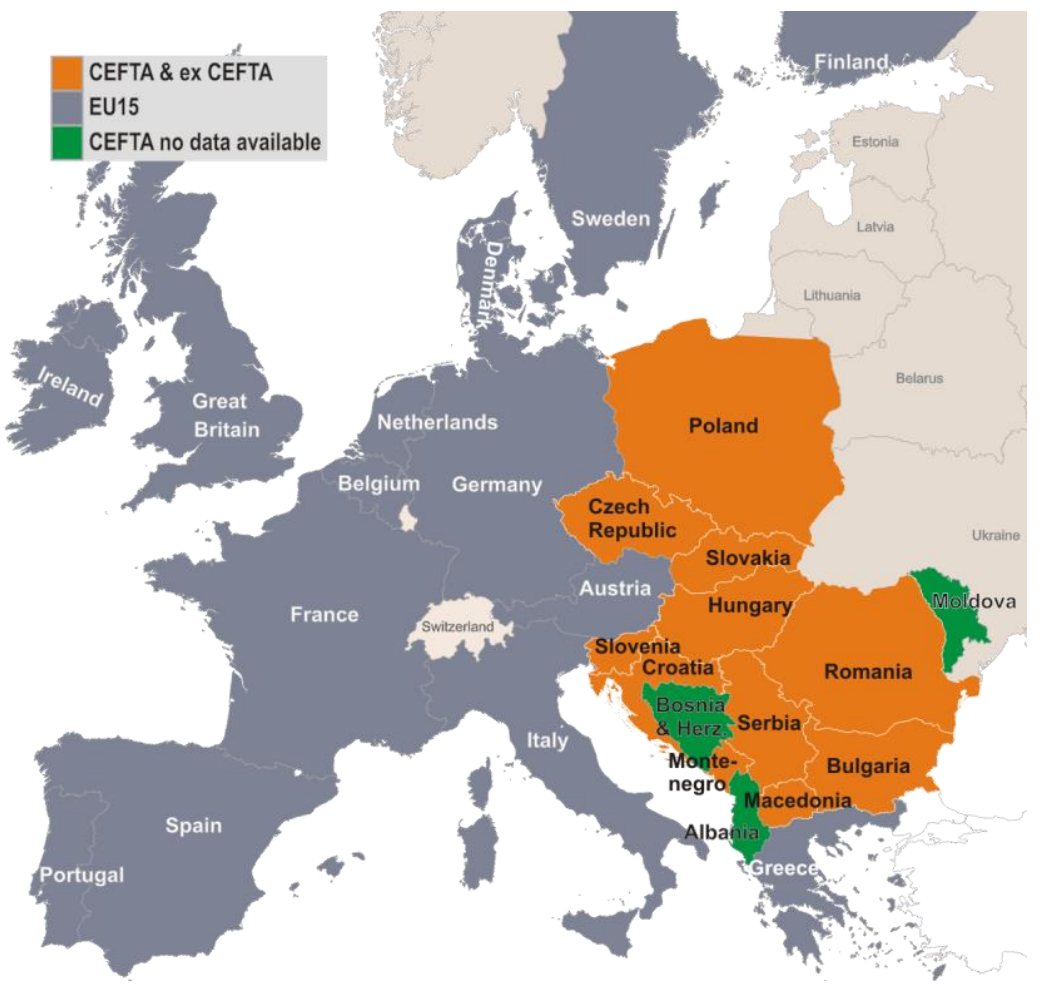

Figure 5 Map of the observed group of countries 
Based on the established model of influence of national competitiveness on economic inequality, the basic hypothesis of the synergistic effect of variables $X_{1}$ and $X_{2}$ on the reduction of economic inequality has been defined:

HA0: Increase in the achieved level of $B \& E$ competitiveness $\left(\mathrm{X}_{1}\right)$ and the level of $I \& S$ competitiveness $\left(\mathrm{X}_{2}\right)$ has a positive synergistic effect on the reduction of economic inequality in the distribution, measured by the Gini coefficient (Y), as an exogenous variable in the model.

In addition to the established basic hypothesis, given the variety of economic structures of European countries, additional hypotheses have been established as well, which should point to the importance of the individual effect of two independent variables on the value of the Gini coefficient:

HA1: Increase in the achieved level of $B \& E$ competitiveness $\left(\mathrm{X}_{1}\right)$ has a positive effect on the reduction of economic inequality in the distribution measured by the Gini coefficient $Y$;

HA2: Increase in the achieved level of $I \& S$ competitiveness $\left(\mathrm{X}_{2}\right)$ has a positive effect on the reduction of economic inequality in the distribution measured by the Gini coefficient Y;

\section{RESEARCH ANALYSIS AND DISCUSSION}

Statistical analysis procedure was realized for each considered group of countries in four steps:

I. In the first step, the homogeneousness of the observed data was examined by descriptive statistics.

II. In the second step, the dependence between the independent variables was examined by means of Pearson correlation coefficient.

III. In the third step, the single correlation between each of independent variables $\left(\mathrm{X}_{1}, \mathrm{X}_{2}\right)$ and dependent variable $(\mathrm{Y})$ is examined.

IV. In the fourth step, using the multiple regression analysis, the overall correlation between both independent variables $\left(\mathrm{X}_{1}\right.$, $\mathrm{X}_{2}$ ) and dependent variable $(\mathrm{Y})$ is determined.

\section{Descriptive Statistics}

The summary statistics of all model variables for the investigated groups of countries is shown in Figures 6, 7, and 8. They present the mean, standard deviation, and coefficients of variation for all variables in the model $\left(\mathrm{X}_{1}, \mathrm{X}_{2}\right.$, and $\left.\mathrm{Y}\right)$. 


\begin{tabular}{rrr}
\hline & $(1)$ & $(2)$ \\
\hline median & 4.33 & 5.19 \\
mean & 4.32 & 5.10 \\
SE.mean & 0.03 & 0.04 \\
CI.mean.0.95 & 0.05 & 0.07 \\
var & 0.07 & 0.16 \\
std.dev & 0.26 & 0.41 \\
coef.var & 0.06 & 0.08 \\
\hline
\end{tabular}

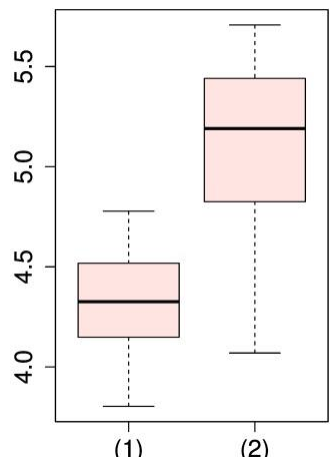

Figure 6 Descriptive statistics for the independent variable $X_{1}(B \& E$ competitiveness) for both groups of countries: (1) CEFTA and (2) EU 15

\begin{tabular}{rrr}
\hline & $(1)$ & $(2)$ \\
\hline median & 3.55 & 5.01 \\
mean & 3.58 & 4.85 \\
SE.mean & 0.04 & 0.06 \\
CI.mean.0.95 & 0.08 & 0.11 \\
var & 0.13 & 0.38 \\
std.dev & 0.36 & 0.62 \\
coef.var & 0.10 & 0.13 \\
\hline
\end{tabular}

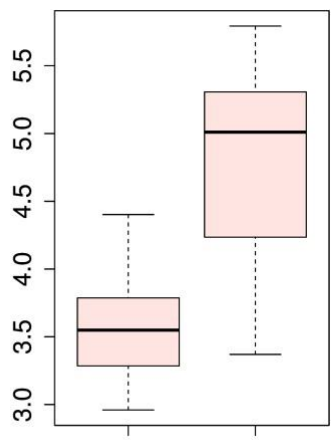

(1) (2)

Figure 7 Descriptive statistics for the independent variable $X 2$ ( $I$ \& $S$ competitiveness) for both groups of countries: (1) CEFTA and (2) EU 15

\begin{tabular}{rrr}
\hline & $(1)$ & $(2)$ \\
\hline median & 30.45 & 29.05 \\
mean & 30.49 & 29.32 \\
SE.mean & 0.60 & 0.31 \\
CI.mean.0.95 & 1.20 & 0.61 \\
var & 32.02 & 11.22 \\
std.dev & 5.66 & 3.35 \\
coef.var & 0.19 & 0.11 \\
\hline
\end{tabular}

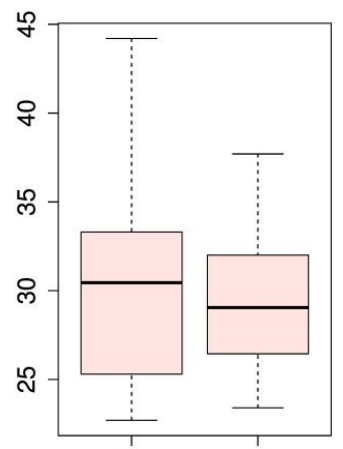

(1) (2)

Figure 8 Descriptive statistics for the dependent variable $Y$ (inequality in income distribution) for both groups of countries: (1) CEFTA and (2) EU15 
Based on the analysis of the summary statistics, it is possible to formulate the following conclusions:

- For both groups of countries, there are no atypical values, related to the extremely positive or negative deviation of the elements in relation to the rest of the population;

- The average values and the quartile and median values of the observed variables that were included in the analysis show that the data is comparable and relatively homogeneous;

- The relatively low coefficients of variation in the independent $\left(\mathrm{X}_{1}\right.$ and $\left.\mathrm{X}_{2}\right)$ and dependent model variables $(\mathrm{Y})$ indicate that these are the variables in which the noise proportion is statistically low, which confirms the potential for predicting the behavior in the initial model.

\section{Multicollinearity}

The obtained, filtered, and structured data was subject to the multiple linear regression analysis:

$$
\mathrm{Y}_{\mathrm{i}}=\beta_{0}+\sum \beta_{\mathrm{ij}} \mathrm{X}_{\mathrm{j}}+\varepsilon_{\mathrm{i},}
$$

where:

$\mathrm{Y}_{\mathrm{i}}-$ dependent endogenous variable,

$\mathrm{X}_{\mathrm{j}}-$ regressor (exogenous, independent variable), and

$\varepsilon_{\mathrm{i}}$ - non-determined random variable (error, noise).

Given that there are three variables in the model $(i=2)$, Fisher's (F) statistics has pointed to the correlation in the model and confirmed the existence of a linear correlation between the dependent variables, $\mathrm{X}_{1}$ and $\mathrm{X}_{2}$ (multicollinearity problem), for both groups of countries, (1) current and former members of CEFTA, and (2) the EU15 countries. The degree of multicollinearity detected (shown in Table 1) exceeds the limit value of the coefficient of determination for the observed population groups (at a level of significance of $1 \%$ ). However, these two variables, in respect of which the multicollinearity was detected $(B \& E$ competitiveness and $I \&$ $S$ competitiveness), are in the model represented by the values of the independent sub-indices of the framework (GCI), which is why the undesirable multicollinearity was abstracted (Allison, 2012). 
Tabela 1 Level of multicollinearity of independent variables (1) CEFTA (2) EU15

\begin{tabular}{lcc}
\hline & \multicolumn{2}{c}{$\mathrm{x} 1$} \\
\cline { 2 - 3 } $\mathrm{x} 2$ & $0.590^{* * * *}$ & $(2)$ \\
\cline { 2 - 3 } Constant & $(0.041)$ & $0.620^{* * * *}$ \\
& $2.200^{* * *}$ & $(0.020)$ \\
\hline Observations & $(0.150)$ & $2.100^{* * * *}$ \\
$\mathrm{R}^{2}$ & 88 & $(0.099)$ \\
Adjusted R & & 120 \\
Residual Std. Error & 0.710 & 0.890 \\
F Statistic & 0.700 & 0.890 \\
\hline Note: & $208.000^{* * * *}(\mathrm{df}=86)$ & $0.140(\mathrm{df}=118)$ \\
& & $929.000^{* * * *}(\mathrm{df}=1 ; 118)$ \\
\hline
\end{tabular}

Single regression analysis

The hypothesis $\mathrm{H} 1$ relates to the influence of the independent variable $\mathrm{X}_{1}$ ( $B \&$ \& $E$ competitiveness) on the dependent variable $\mathrm{Y}$ (economic inequality). The hypothesis $\mathrm{H} 2$ refers to the influence of the independent variable $\mathrm{X}_{2}$ (I \& $S$ competitiveness) on the dependent variable $\mathrm{Y}$ (economic inequality).

For both groups of countries, the correlation between the observed pairs of variables was analyzed, through a single linear correlation, expressed by Pearson's coefficient, as given in Table 2.

Table 2 Summary of single regression analysis ((1) CEFTA countries, (2) EU15 countries)

\begin{tabular}{|c|c|c|c|c|}
\hline & \multicolumn{4}{|c|}{ Dependent variable: } \\
\hline & & & $Y$ & \\
\hline & (1) & (1) & (2) & (2) \\
\hline $\mathrm{x} 1$ & $\begin{array}{c}-14.000^{* * * *} \\
(1.800)\end{array}$ & & $\begin{array}{c}-5.900^{* * * *} \\
(0.530)\end{array}$ & \\
\hline $\mathrm{x} 2$ & & $\begin{array}{c}-11.000^{* * * *} \\
(1.200)\end{array}$ & & $\begin{array}{c}-4.300^{* * * *} \\
(0.300)\end{array}$ \\
\hline Constant & $\begin{array}{c}90.000^{* * * *} \\
(8.000)\end{array}$ & $\begin{array}{c}69.000^{* * * *} \\
(4.400) \\
\end{array}$ & $\begin{array}{c}60.000^{* * * *} \\
(2.700)\end{array}$ & $\begin{array}{c}50.000^{\text {***** }} \\
(1.500) \\
\end{array}$ \\
\hline Observations & 88 & 88 & 120 & 120 \\
\hline $\mathrm{R}^{2}$ & 0.400 & 0.470 & 0.510 & 0.630 \\
\hline Adjusted $\mathrm{R}^{2}$ & 0.390 & 0.470 & 0.510 & 0.630 \\
\hline Residual Std. Error & $4.4(\mathrm{df}=86)$ & $4.1(\mathrm{df}=86)$ & $2.3(\mathrm{df}=118)$ & $2.0(\mathrm{df}=118)$ \\
\hline F Statistic & $\begin{array}{c}56^{* * * *} \\
(\mathrm{df}=1 ; 86)\end{array}$ & $\begin{array}{c}77^{* * * *} \\
(\mathrm{df}=1 ; 86)\end{array}$ & $\begin{array}{c}125^{* * * *} \\
(\mathrm{df}=1 ; 118) \\
\end{array}$ & $\begin{array}{c}203^{* * *} \\
(\mathrm{df}=1 ; 118) \\
\end{array}$ \\
\hline
\end{tabular}


Figure 9 shows the dependence of economic inequality on the independent variables $\mathrm{X}_{1}$ and $\mathrm{X}_{2}$, obtained by single linear regression.
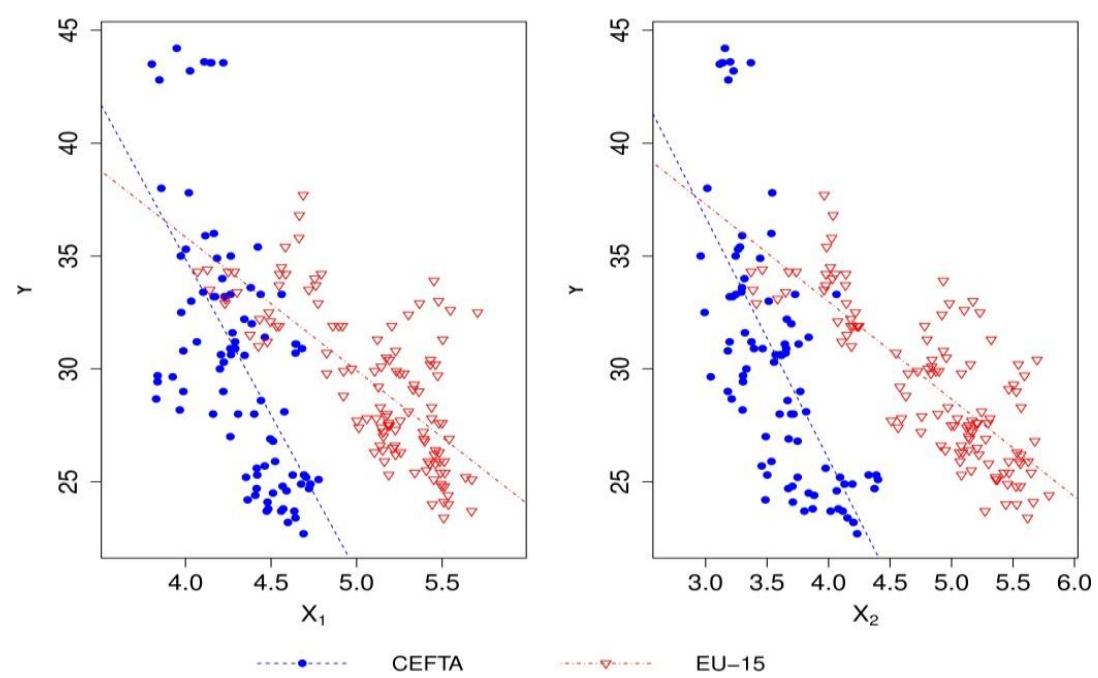

Figure 9 Dependence of economic inequality on a) $B \& E$ competitiveness and b) I \& $S$ competitiveness, for both groups of countries

Analysis of the results for both groups of countries has pointed to a desirable negative correlation between the observed variables, which is statistically significant in all observed pairs (at the level of significance of $1 \%)$. In both groups of countries, the positive effect of the variable $\mathrm{X}_{1}(B \& E$ competitiveness) on the decrease in the dependent variable $\mathrm{Y}$ is about $25 \%$ stronger than the influence of the variable $\mathrm{X}_{2}(I \& S$ competitiveness $)$. Observed by groups, the influence of the observed independent variables on the reduction of economic inequality is about $40 \%$ stronger in group (1), CEFTA countries, in relation to group (2), the EU15 countries.

Previous analysis of the influence of $\mathrm{X}_{1}$ on $\mathrm{Y}$ (hypothesis H1), and of $\mathrm{X}_{2}$ on $\mathrm{Y}$ (hypothesis $\mathrm{H} 2$ ) has pointed to a significant positive influence of both $B \& E$ competitiveness and $I \& S$ competitiveness on the decrease in the levels of economic inequality in both groups of the observed countries, which confirms the hypotheses H1 and H2 (Figure 10).

\section{Multiple regression analysis}

The basic research hypothesis, H0, refers to the synergistic effect of the influence of explanatory independent variables, $X_{1}$ and $X_{2}$, on the dependent variable Y. Statistical processing of data under this part of the research has pointed to the dependence defined in mathematical expression (3) and shown in Table 3. 


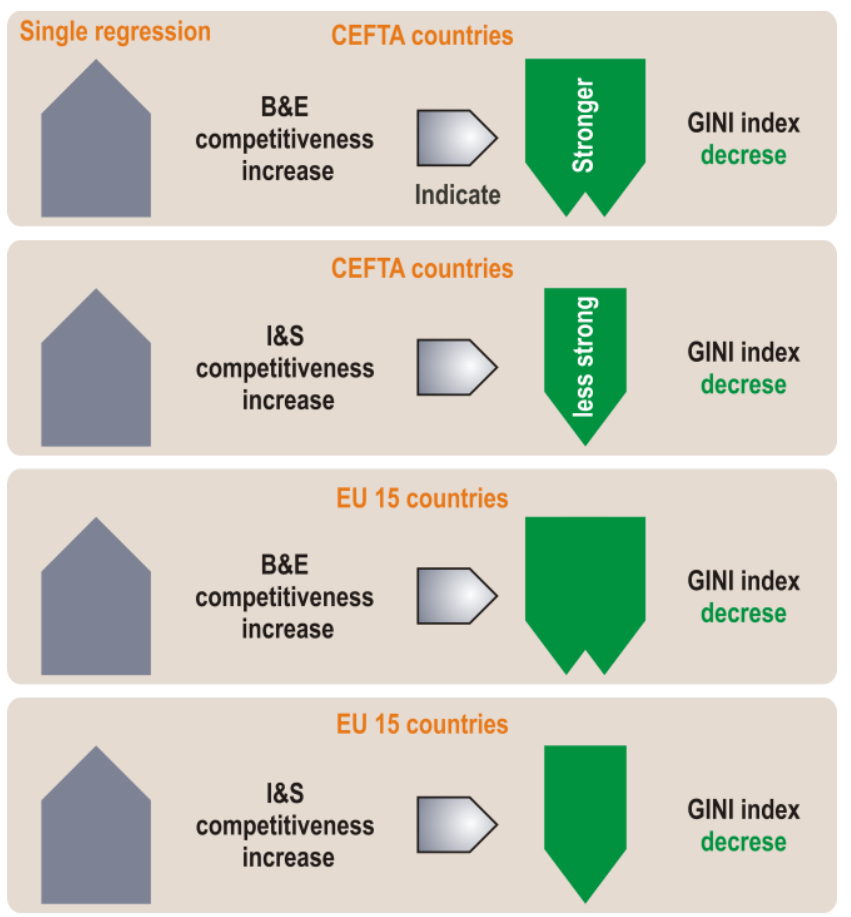

Figure 10 Summary of results of simple regression analysis

Table 3 Summary of multiple regression analysis ((1) CEFTA countries, (2) EU15 countries)

\begin{tabular}{lcc}
\hline & \multicolumn{2}{c}{ Dependent variable: } \\
\cline { 2 - 3 } & $(1)$ & $(2)$ \\
\hline $\mathrm{x} 1$ & -3.800 & $2.400^{*}$ \\
& $(3.200)$ & $(1.400)$ \\
$\mathrm{x} 2$ & $-8.400^{* * * *}$ & $-5.800^{* * *}$ \\
& $(2.200)$ & $(0.900)$ \\
Constant & $77.000^{* * * *}$ & $45.000^{* * * *}$ \\
& $(8.200)$ & $(3.200)$ \\
\hline Observations & 88 & 120 \\
$\mathrm{R}^{2}$ & 0.480 & 0.640 \\
Adjusted $\mathrm{R}^{2}$ & 0.470 & 0.640 \\
Residual Std. Error & $4.100(\mathrm{df}=85)$ & $2.000(\mathrm{df}=117)$ \\
F Statistic & $40^{* * * *}(\mathrm{df}=2 ; 85)$ & $105^{* * *}(\mathrm{df}=2 ; 117)$ \\
\hline \multicolumn{1}{c}{ Note: } & & ${ }^{*} \mathrm{p}<0.1 ;{ }^{* *} \mathrm{p}<0.05 ;{ }^{* * * *} \mathrm{p}<0.01$
\end{tabular}


Figures 11 and 12 show the graphical interpretation of multiple regression model of influence of both explanatory, i.e. independent variables on the dependent variable economic inequality for both groups of countries.

(1) Results for group (1) - CEFTA countries show statistically significant influence, because the variables $X_{1}$ and $X_{2}$ with coefficient of determination $\mathrm{R}=0.69$ affect the variable $\mathrm{Y}$. Furthermore, in this group of countries, both independent variables $\left(\mathrm{X}_{1}\right.$ with the factor -3.8 and $\mathrm{X}_{2}$ with the factor -8.4) have the pronounced desirable negative effect on the dependent variable $\mathrm{Y}$ (provided that the effect of the variable $\mathrm{X}_{2} I \& S$ competitiveness is about 2.2 times stronger).

$$
\begin{gathered}
\mathrm{Y}=77-3.8 * \mathrm{X}_{1}-8.4 * \mathrm{X}_{2}+\mathrm{e} \\
\mathrm{R}^{2}=0.48 ; \text { adjusted } \mathrm{R}^{2}=0.47 ; \mathrm{e}=4.1
\end{gathered}
$$

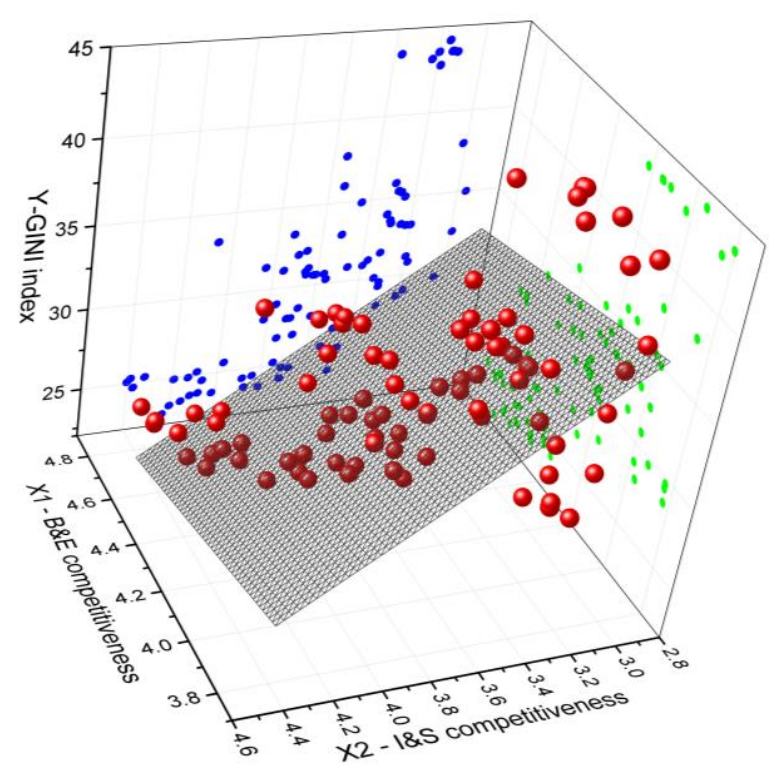

Figure 11 Three-dimensional presentation of the dependence of economic inequality on $B \& E$ competitiveness and I \& S competitiveness in the group (1), CEFTA

(2) The results for group (2) - EU15 countries show higher statistical significance of influence than it is the case with group (1), since the variables $\mathrm{X}_{1}$ and $\mathrm{X}_{2}$ with the coefficient of determination $\mathrm{R}=0.8$ influence the variable $\mathrm{Y}$. However, in this group, variable $\mathrm{X}_{1}$ has an undesirable positive effect with a factor of 2.4, while variable $\mathrm{X}_{2}$, as in group (1), with the factor -5.8 , has a significantly higher, but desirable negative effect (absolute influence of variable $\mathrm{X}_{2}$ on $\mathrm{Y}$ is about 2.4 times higher than the influence of variable $\mathrm{X}_{1}$ ). 


$$
\begin{gathered}
\mathrm{Y}=45+2.4 * \mathrm{X}_{1}-5.8 * \mathrm{X}_{2}+\mathrm{e} \\
\mathrm{R}^{2}=0.64 ; \text { adjusted } \mathrm{R}^{2}=0.64 ; \mathrm{e}=2
\end{gathered}
$$

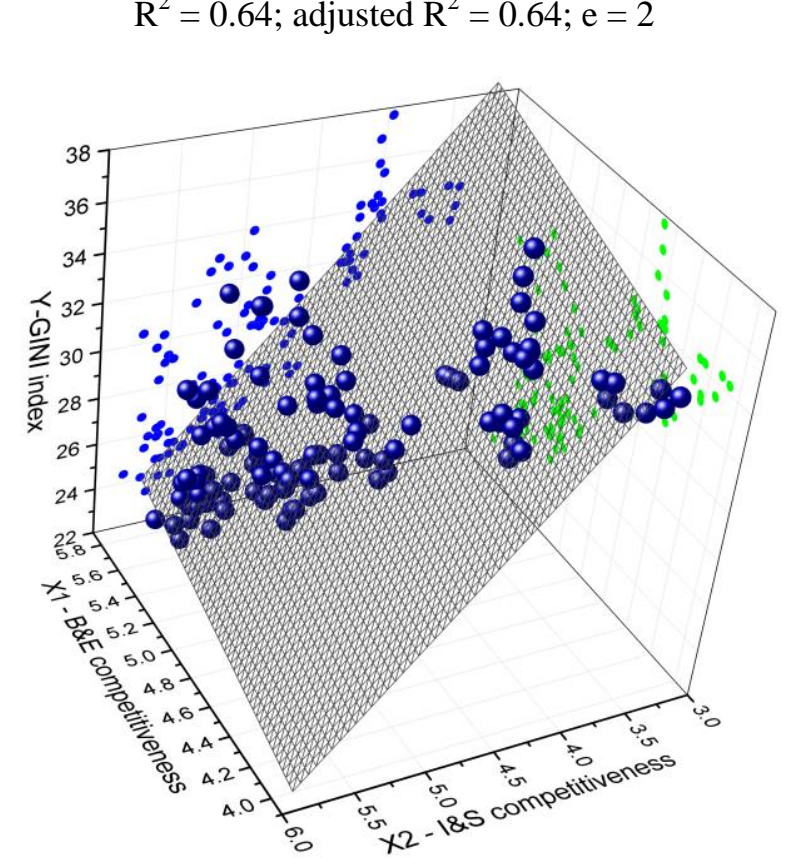

Figure 12 Three-dimensional presentation of the dependence of economic inequality on $B \& E$ competitiveness and I \& S competitiveness in the group (2) EU15

Multiple regression analysis shows different intensities, but also signs of the influence of independent variables on the economic inequality in the model, depending on the observed group. In group (1), CEFTA, there is the dominance of the desirable negative effect of the variable $\mathrm{X}_{2}(I \& S$ competitiveness) on $\mathrm{Y}$, in relation to the influence of $\mathrm{X}_{1}(B \& E$ competitiveness), which is also negative, but significantly weaker. In contrast, in group (2), EU15, this influence of the independent variables has the opposite signs (variable $\mathrm{X}_{2}$ has a dominant and desirable negative influence, whereas variable $X_{1}$ has a weaker and a positive influence on the dependent variable Y). The analysis also shows that, in the CEFTA countries, the statistical significance of the model is much lower compared to the EU15.

From the standpoint of the established key hypothesis, H0, which the model tested, based on the analysis of the synergistic influence of $\mathrm{X}_{1}$ and $\mathrm{X}_{2}$ on $\mathrm{Y}$ (testing the hypothesis $\mathrm{H} 0$ ), one can conclude that: 
- In group (1), CEFTA, the established positive and statistically significant influence of both independent variables on the decrease in economic inequality points to the existence of synergistic potential in the model. However, multiple regression analysis has not pointed to the realization of a synergistic effect of explanatory independent variables in the model: a) The total coefficient of correlation of variables $X_{1}$ and $X_{2}$ of $R=0.69$ is the same as the highest individual coefficient of correlation of variable $\mathrm{X}_{2}(I \& S$ competitiveness $(\mathrm{R}=0.69)$ and $\mathrm{b})$ both independent variables, analyzed individually through simple regression, show higher factors of influence on Y (Gini coefficient), in relation to their joint effect, analyzed by multiple regression;

- In group (2), EU15, the hypothesis $\mathrm{H0}$ is rejected due to conflicting effects of independent variables in the multiple regression model, as compared to a simple regression model, where both studied independent variables showed a desirable negative effect on the dependent variable Y (Gini coefficient) (Figure 13).

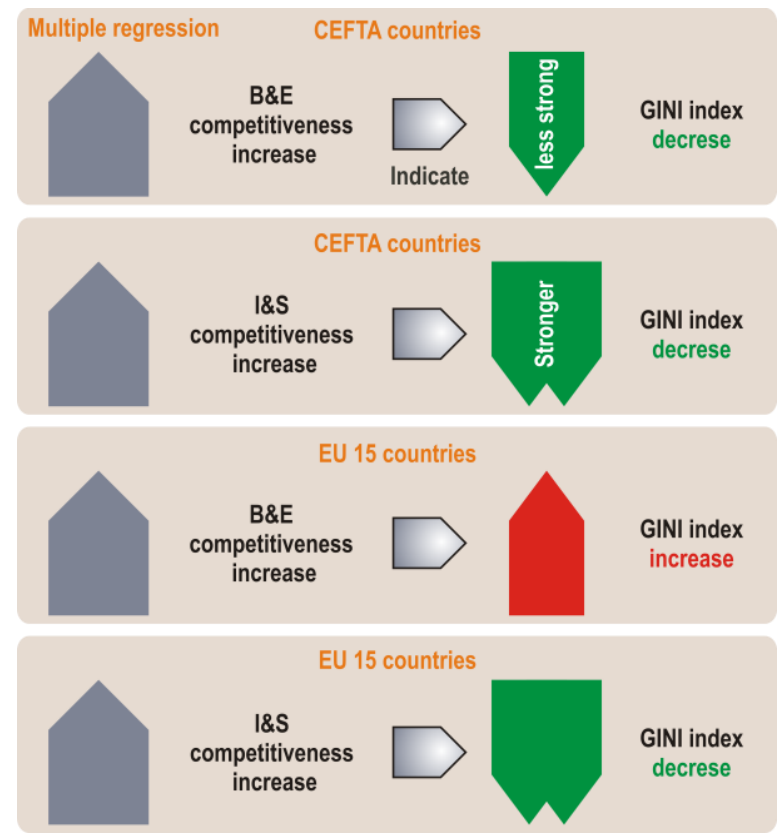

Figure 13 Summary of results of multiple regression analysis

Such a change of significance, and of the very sign of the influence of $B \& E$ competitiveness and $I \& S$ competitiveness on economic inequality of the observed groups may be due to a difference in the achieved level of GDP per capita as well as the status of EU membership. However, we think that 
this can be an interesting starting point for further research. One of the directions of authors' further research will be the analysis of the interconnectedness and the influence of integral indicators of composite indices, $B \& E$ competitiveness and $I \& S$ competitiveness, on the Gini index (for example, by using PCA - Principal Component Analysis).

\section{CONCLUSION}

The results show that:

- $B \& E$ competitiveness (variable $\mathrm{X}_{1}$ ), as a representative of the basic competitiveness of the economy, has a statistically significant influence on the Gini coefficient. In the group of CEFTA countries with the coefficient of influence of about -3.8 , increase in variable $X_{1}$ decreases the Gini coefficient, unlike EU15 group, where this influence has a positive sign with a coefficient of around 2.4 (increase in variable $\mathrm{X}_{1}$ increases the Gini coefficient).

- $I \& S$ competitiveness (variable $\mathrm{X}_{2}$ ), as a representative of Competitiveness based on innovation and business sophistication, has a statistically significant effect on the decrease in the Gini coefficient in both groups of the observed countries: a) in the CEFTA group, the coefficient of influence is about -8.4 (increase in the variable $\mathrm{X}_{2}$ affects approximately 8.4 times the decrease in the Gini coefficient), b) in EU15 group, this influence is somewhat weaker, amounting to -5.8 (increase in the variable $\mathrm{X}_{2}$ affects around 5.8 times the decrease in the Gini coefficient).

Today's CEFTA countries should use the strategic competitiveness improvement policies (and a regional approach to innovation strategies) to significantly reduce inequality in the distribution of income, represented by the Gini coefficient.

\section{REFERENCES}

Aghion, P., Akcigit, U., Bergeaud, A., Blundell, R., \& Hémous, D. (2015). Innovation and Top Income Inequality. Harvard University, mimeo.

Allison, P. (2012). When can you safely ignore multicollinearity. Statistical Horizons, 5(1). Bogliacino, F. (2013). GINI Policy Paper 1: The inequality content of some of the Europe 2020 flagships (No. 1). AIAS, Amsterdam Institute for Advanced Labour Studies.

Cvetanović, S., \& Novaković, I. (2014). Inovativnost i održiva konkurentnost [Innovation and Sustainable Competitiveness]. Niš: Filozofski fakultet, Univerzitet u Nišu.

Despotovic, D. Z., Cvetanović, S. Ž., \& Nedić, V. M. (2014). Innovativeness and competitiveness of the Western Balkan countries and selected EU member states. Industrija, 42(1), 27-45.

Despotovic, D., Cvetanovic, S., Nedic, V., \& Despotovic, M. (2015). Economic, social and environmental dimension of sustainable competitiveness of European countries. Journal of Environmental Planning and Management, Vol. 58, 1-23. 
Dragičević, M. 2012. Konkurentnost: Projekat za Hrvatsku [Competitiveness: A project for Croatia]. Zagreb: Školska knjiga.

Gini coefficient of equivalised disposable income. (n.d.). Retrieved January 16, 2015, from $\mathrm{http} / /$ ec.europa.eu/eurostat/tgm/table.do?tab=table\&language=en\&pcode=tessi19 0 . EuroStat.

Gottschalk, P., \& Smeeding, T. M. (2000). Empirical evidence on income inequality in industrialized countries. Handbook of income distribution, 1, 261-307.

Huangbao, G. (2014). Based on the Theil Entropy and Gini Coefficient. Journal of Applied Sciences, 14(4), 333-340.

Huggins, R., \& Izushi, H. (2009). Regional benchmarking in a global context: knowledge, competitiveness, and economic development. Economic Development Quarterly, 23(4), 275-293.

Kawachi, I., \& Subramanian, S. V. (2014). Income inequality. Social epidemiology, 126.

Ketels, C. (2003) Thailand's competitiveness: Key issues in five clusters.Unpublished mss., Harvard Business School, Cambridge, Mass. Processed

Kitson M., Martin, R., Tyler P. (2004) Regional Competitiveness: An Elusive yet Key Concept? Regional Studies 38(9): 991-999

Krugman, P., (1996) Making sense of the competitiveness debate. Oxford review of economic policy, 17-25

Lundvall, B. _., \& Rodrigues, M. J. (Eds.). (2002). The New Knowledge Economy in Europe: a strategy for international competitiveness and social cohesion. Edward Elgar Publishing.

Lundvall, B. A., \& Lorenz, E. (2012). From the Lisbon strategy to Europe 2020.Towards a social investment welfare state, 333-351.

Martin, R., Kitson, M., \& Tyler, P. (Eds.). (2012). Regional competitiveness. Routledge.

Martin, S., Schwab, K., \& Porter, M. E. (2012). The Global Competitiveness Report 20072008.

Milanovic, B. (2002). Can we discern the effect of globalization on income distribution? Evidence from household budget surveys. The World Bank.

Nijkamp, P., Siedschlag, I., \& Smith, D. (2011). Economic growth, innovation and competitiveness in a knowledge-based world economy: introduction. In Innovation, Growth and Competitiveness (pp. 1-11). Springer Berlin Heidelberg.

Page, S., \& Vandermeer, J. (2013). Inequality and Innovativeness. Available at SSRN 2227002.

Porter, M. E., Sachs, J., Cornelius, P. K., McArthur, J. W., \& Schwab, K. (2004). The global competitiveness report 2004-2005. New York, NY: Palgrave Macmillan.

Sala-i-Martin, X., Dervis, K., Hausmann, R., Bascuñán, H. D. F. L., \& Pangestu, H. D. M. E. (2010). The Global Competitiveness Report 2010-2011: Highlights. In World Economic Forum.

Schwab, K., \& Porter, M. E. (Eds.). (2007). The global competitiveness report 2007-2008. Basingstoke: Palgrave Macmillan.

Schwab, K., \& Sala-i-Martin, X. (2015). World Economic Forum's Global Competitiveness Report, 2014-2015. WEF..

Stiglitz, J. (2015). The Great Divide. Penguin UK.

Waheeduzzaman, A. N. M. (2002). Competitiveness, human development and inequality: A cross-national comparative inquiry. Competitiveness Review: An International Business Journal, 12(2), 13-29.

WEF (2015) The Global Competitiveness Report 2015-2016. World Economic Forum, Geneva.

World Development Indicators, World DataBank. (n.d.). Retrieved January 16, 2015, from http://databank.worldbank.org/data/reports.aspx?source=world-developmentindicators. World Bank. 


\title{
КОНКУРЕНТНОСТ И НЕЈЕДНАКОСТ У РАСПОДЕЛИ ДОХОТКА ЗЕМАЉА ЕВРОПЕ РАЗЛИЧИТОГ НИВОА РАЗВИЈЕНОСТИ
}

\author{
Владимир Костић ${ }^{1}$, Војислав Илић ${ }^{2}$, \\ Слободан Цветановић ${ }^{3}$, Владимир Недић ${ }^{4}$ \\ ${ }^{1}$ Универзитет у Косовској Митровици, Економски факултет, Србија \\ ${ }^{2}$ Универзитет у Косовској Митровици, Факултет уметности; \\ Универзитет у Крагујевцу, Филолошко-уметнички факултет, Србија \\ ${ }^{3}$ Универзитет у Нишу, Економски факултет, Србија \\ ${ }^{4}$ Висока техничка школа струковних студија, Крагујевац, Србија
}

\section{Резиме}

У раду је истраживана међузависност феномена конкурентности и неједнакости у расподели дохотка земаља европског континента различитог нивоа економске развијености у периоду 2006-2013. Анализиране земље су подељене у две групе: а) садашње (Албанија, Црна Гора, БИХ, Македонија, Молдавија и Србија) и некадашње чланице (Бугарска, Хрватска, Мађарска, Пољска, Словачка, Словенија, Румунија и Чешка) Централноевропског Споразума о слободној трговини ЦЕФТА и б) земље ЕУ15. Прва групу представљају мање конкурентне, а другу високо конкурентне европске земље. Достигнути ниво конкурентности је исказиван величином Глобалног индекса конкурентности (ГЦИ) Светског економског форума, декомпонованог на две скаларне вредности: а) тзв. конкурентност засновану на Основним факторима Ефикасности (Basic \& Efficiency factors competitiveness) и б) конкурентност генерисану факторима пословне иновативности и софистицираности (Innovation \& Sophistication factors competitiveness). Неједнакост у расподели дохотка је презентована величином Гини коефицијента. У циљу доказивања постављених хипотеза да конкурентније привреде имају мање изражену неједнакост у расподели дохотка конструисан је модел међузависности конкурентности привреде (репрезентованом вредностима ГЦИ) и неједнакости у расподели дохотка (квантифициране вредношћу Гини коефицијента). Поступак статистичке анализе овог утицаја реализован је у три корака: а) анализом референтног фрејмворка Глобалног индекса конкурентности за идентификацију испитиваних варијабли, преузимањем, филтрирањем и структуирањем доступних података, б) статистичком провером временске серије података у циљу утврђивања њиховог степена хомогености и конзистентности, који су графички представљени бокс плот дијаграмима и в) применом линеарне једноструке и вишеструке регресионе анализе за истраживање међузависности конкурентности и испољене нејеједнакости у расподели дохотка мерене вредношћу Гини коефицијента за обе посматране групе земаља. На основу креираног модела зависности Гини коефицијента од поменутих компоненти конкурентности, помоћу просте и вишеструке линеарне регресионе анализе дошло се до закључка да достигнути ниво конкурентности појединих земаља има статистички значајан утицај на величину Гини коефицијента. Резултати вишеструке линеарне регресије показују да је код групе ЦЕФТА земаља коефицијент утицаја Basic \& Efficiency factors based competitiveness око 3.8 , док је код групе ЕУ15 око 2.4. Такође, истраживање је потврдило статистички значајни утицај Innovation \& Sophistication factors competitiveness на смањење Гини коефицијента код обе групе посматраних земаља; код ЦЕФТА групе коефицијент утицаја је око -8.4 а код ЕУ15 тај утицај је нешто слабији и износи -5.8. Ово 
значи да би некадашње и нарочито данашње земље ЦЕФТА одговарајућим политикама иновација могле значајније да унапреде властиту конкурентност, што би, поред осталог, засигурно деловало на смањење неједнакости у расподели доходака у њима. Да би боље разумели утицај појединих компоненти конкурентности на неједнакост у расподели доходака појединих земаља, даља истраживања би могла ићи у смеру испитивања, која узимају у обзир утицај достигнутог нивоа појединих индикатора композитних стубава ГЦИ а) 12. стуб - Иновативност и б) 11- стуб Софистицираност тржишта. Све ово наводи на императив да земље ЦЕФТА групације у датом моделу, могу смањити изражену неједнакост у расподели дохотка под условом да своју конкурентност граде на убрзаном расту иновативности и унапређењу тржишне софицтицираности. Основна порука је да ове земље морају да властите стратегије конкурентности у далеко већем степену базирају на расту иновативности и софистицираности тржишта. Ово разумљиво, није једноставан задатак, али сасвим сигурно да унапређење конкурентности земаља у економији знања на онову раста иновативности представља имплицитну претпоставку њиховог дугорочно одрживог развоја који у себи садржи и компоненту смањења неједнакости у расподели дохотка. 